\title{
MT3 Gene
}

National Cancer Institute

\section{Source}

National Cancer Institute. MT3 Gene. NCI Thesaurus. Code C29956.

This gene is involved in cellular growth regulation and is expressed exclusively in the nervous system. 